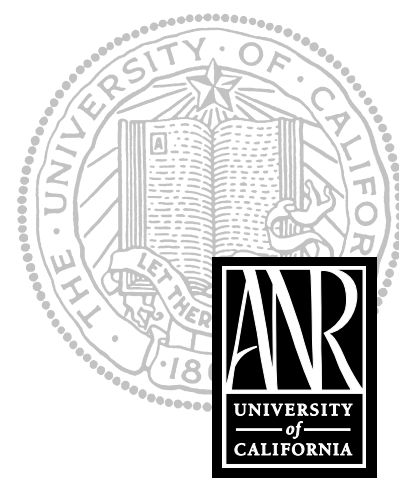

UNIVERSITY OF CALIFORNIA

Agriculture and Natural Resources

http://anrcatalog.ucdavis.edu
PUBLICATION $\mathbf{8 0 2 9}$

\section{Cilantro Production: Sample Costs and Profitability Analysis}

\section{Based on 1999 Data Collected in Ventura County, California}

\begin{abstract}
Etaferahu Takele, Area Farm Advisor, Agricultural Economics and Farm Management, UC Cooperative Extension in Southern California.
\end{abstract}

The author wishes to express her appreciation to the University of California, Division of Agriculture and Natural Resources, Thelma Hansen Trust for funding this project. She also expresses her appreciation to those growers and other cooperators who provided data and review in the development of this study.

This study presents sample costs of production for fresh-market cilantro developed in Ventura County, California, in 1999, but the methodology we used to analyze costs, profits, and investments can easily be modified to address individual situations in production areas throughout California. Tables 1 and 2 include a "Your cost" column where growers can enter their own costs for comparison with ours. Also note that because of rounding, the totals given in tables 1 through 6 may differ slightly from the sums of their constituent numbers.

We based our study on certain assumptions that we developed from production practices and cost information gathered from growers and agricultural institutions in the area. This is one of a series of six reports on vegetable crop production that are based on Ventura County data.

As a grower or other agriculture professional, you can benefit from this report in many ways. It can help you make production decisions, determine potential returns, prepare budgets, evaluate production loans and analyze policies.

A discussion of the assumptions and calculation methods used in this study is provided in the text. Cultural practice and cost data are presented in detail in six tables:

Table 1. Costs per acre to produce cilantro

Table 2. Costs and returns per acre to produce cilantro

Table 3. Monthly cash costs per acre to produce cilantro

Table 4. Range analyses of cilantro production costs and returns

Part A. Costs per acre and per carton at varying yields

Part B. Returns per acre above operating costs

Part C. Returns per acre above all cash costs (gross margin)

Part D. Returns per acre above total costs (returns to management)

Table 5. Farm equipment and investment values and annual costs

Table 6. Farm equipment actual hours of use and hourly costs 


\section{STUDY ASSUMPTIONS}

This report is based on a 1,300-acre vegetable farm, the average size of farm for the growers we interviewed. Most land used for vegetable crops in Ventura County produces two or more crops a year. Each crop is planted and harvested several times a year, so planting, harvesting, and selling of vegetable crops are year-round activities for growers, farm workers, and sellers.

We calculated our costs assuming that at least two crops are produced on each acre, resulting in a total of 2,600 acres of farmed land per year. For our study, the crops grown on the farm include broccoli, bell pepper, celery, spinach, loose-leaf lettuce, and cilantro (we have issued a report similar to this one for each of these crops). This crop mix is not present, of course, on every farm in Ventura County, but several farms in our interview pool did produce all six crops.

The growing period for each crop varies depending on time of planting. Consequently, production costs-particularly for irrigation, disease and pest management, and overhead - would be expected to vary. We based our study on an average growth period of minimum and maximum days. Prices used for materials, equipment, contract services, and labor wages (unless otherwise specified) are for the year 1999.

\section{CULTURAL PRACTICES AND PRODUCTION INPUTS}

Land preparation. Different types of fields and management preferences require different types of land preparation. Most growers in our interview pool performed several operations including multiple discing (five times in this study), ripping the soil (maybe twice) to break up any underlying compacted soil, plowing, leveling using a triplane, chiseling, furrowing, listing, and shaping beds. Preplant fertilizer was applied together with the listing operation before the ground was shaped and rolled into beds. The ground is preirrigated after the ground is shaped and rolled into beds.

Stand establishment. Cilantro is grown primarily on the Central Coast of California. It is commonly referred to as Mexican parsley, Chinese parsley, and coriander. Cilantro types include Santos, Long Standing, Slo Bolt, and Leisure, and all have similar cultural, harvesting, and marketing requirements. Seeding is at approximately 25 pounds per acre.

Weed management. Cilantro is considered a minor crop in the state of California. There are no herbicides registered for preventing weed infestations in cilantro. Mechanical cultivation and hand hoeing are the principal means of controlling weeds.

Fertilization. As mentioned previously, preplant fertilizer of nitrogen and phosphorous is in most cases applied together with the listing before the ground is shaped and rolled into beds.

Fertilizer applications are mostly $\mathrm{N}$ and are applied via the furrow irrigation system. The amount and type of fertilizer we included in this study are based on an average of what most growers applied.

Irrigation. Prior to planting and during germination, irrigation is applied with a sprinkler system. Growers can purchase or rent sprinkler irrigation systems. We calculated costs for this study based on ownership of an existing sprinkler irrigation system.

Growers can irrigate a field one portion at a time, moving pumps, pipes, and fittings manually from field to field. For this study, we assumed that sufficient pumps, 
pipes, and fittings are available to irrigate 430 acres at a time. Pipes are transported using a trailer and a tractor. Spreading the pipes takes 90 minutes of manual labor per acre. Removing pipes takes about the same amount of time.

After seedlings have broken through the soil, growers switch to a furrow irrigation system. Irrigation labor for inspection and maintenance of the system is estimated at about 30 minutes per acre per irrigation for sprinklers and about 20 minutes per acre per irrigation for furrow irrigation.

Energy use for pumping includes both diesel fuel and electric power, depending on the irrigation system. The amount of diesel and electricity consumption depends on pump horsepower (hp). In our study, we used $100 \mathrm{hp}$ for a diesel pump and 70 hp for an electric pump. We estimated that 24 gallons per acre of diesel and about 269 kilowatts $(\mathrm{kW})$ of electricity per acre would be needed during the production period for cilantro.

The cost of water to irrigate crops varies greatly from region to region in Ventura County and also depends on whether district or well water is used. In this study, production is in the Oxnard plains where growers use both well and district water. We calculated the water cost at $\$ 82$ per acre-foot. This rate is a weighted average for pumping costs and district charges, assuming that one-third of the water comes from wells and the remaining two-thirds from districts. Commonly, an irrigation of a cilantro crop uses about 12 acre-inches of water.

Pest and disease management. Insects that can affect cilantro production during the growth period include beet armyworm (Spodoptrera exigua), cabbage looper (Trichoplusia ni), and green peach aphid (Myzus persiczae). Most of these pests can be treated at the larval stage. Growers usually rotate insecticides in order to slow potential pest resistance. Written recommendations from State of California licensed pest control advisors are required for pesticide use. For information and pesticide use permits, contact your county Agricultural Commissioner's office. You can also obtain pest management information on the UC Statewide Integrated Pest Management Project website, http://www.ipm.ucdavis.edu.

Soilborne pests such as root knot nematodes (Melodidogyne spp.) are an isolated problem and are usually controlled with soil fumigation. In this study, we did not include soilborne pest control. Growers are advised to adjust their management practices as necessary.

Cilantro is a fairly disease-free crop in California. Bacterial leaf spot (Pseudomonas syringae pv. Coriandricola) can sometimes be a serious problem. Clean seed and using furrow or drip irrigation to help maintain dry foliage are the most effective means of control.

\section{HARVEST AND SELL}

Cilantro is field packed in cartons. Each carton typically contains about 30 bunches and weighs 20 pounds. After the cilantro is packed, it is quickly transported to a storage facility where it is cooled and palletized at a scientifically recommended temperature.

Harvesting costs in this study include cartons, picking and packing, and loading and hauling to the nearest cooling facility. We estimated a cost of $\$ 0.80$ for the carton itself, $\$ 0.80$ per carton for picking and packing, and $\$ 0.65$ per carton for loading and hauling. Selling cost is estimated at $\$ 0.50$ per carton. We did not include cooling costs because we did not have sufficient information on how much or for how long growers pay for using cooling facilities. 


\section{INTEREST ON OPERATING CAPITAL}

We calculated interest on operating capital at a nominal rate of 10 percent per year. Interest on operating capital reflects the costs of borrowing money or an opportunity cost for using in-house funds. Interest on operating capital is charged until income is received from the crop at harvest. A nominal interest rate is the current market cost of borrowed funds during the production year.

\section{DISPOSING OF CROP RESIDUE}

After harvest, the field is disced twice to incorporate all crop residues into the soil.

\section{CASH OVERHEAD COSTS}

Land rent. Land rental contracts and charges for agricultural production can vary widely by region and also depend on the availability of well water on the property. In Ventura County, if there is a well on the property, the landlord often pays for the pump, the permanent parts of the irrigation facilities, and the costs of maintaining the well. The grower is generally responsible for the costs of energy needed to pump water.

Most of the growers we interviewed rented land with wells that provide a portion of their farms' water requirements. We do not have sufficient data, however, to compare land rent for properties with and without well water. We suggest that growers evaluate the value and costs associated with well water and take this into account when determining an appropriate cost for land rent.

This study assumes an average cash rent of $\$ 1,320$ per acre per year $(\$ 110$ per acre per month). Using a 3-month average growth period from land preparation to harvest, the cilantro enterprise is charged a rent of $\$ 330$ per acre per crop.

Property taxes. Counties charge a base property tax rate of 1 percent on the assessed value of the property, including equipment, buildings, and improvements. Special assessment districts in some counties charge additional taxes on property. For our study, we calculated county taxes at 1 percent of the value of the property.

Insurance. Growers also carry insurance for property protection, which is typically calculated at 0.713 percent of the average value of assets. In addition, a farm of the size specified in this report would carry liability insurance of $\$ 1,040$ per year to cover accidents on the entire farm.

Supervisors, foremen, and management. Interview information indicated that the size of farm we used in this study would require an average of about three employees working as supervisors or foremen. Wages are estimated at $\$ 110$ per acre per year. For the 3-month growth period, the cilantro enterprise is charged $\$ 27$ per acre per crop for supervisors and foremen.

Most growers in the survey did not provide management costs, and the wide variations in wages and salaries for professional managers make it difficult to approximate a typical situation. We suggest that, after all production costs have been subtracted from receipts, the residual should be referred to as returns to management.

Office expenses. Expenses in this category include office supplies, telephone service, operating costs for a fax machine, photocopier, and computer, bookkeeping, accounting, legal fees, and so on. Our interview average for office expenses is about $\$ 360$ per acre per year. For the 3 months of cilantro crop production, office expenses are around $\$ 90$ per acre per crop. 


\section{NON-CASH OVERHEAD COSTS}

We calculated the non-cash overhead or ownership costs of assets (including farm equipment and other investments like an irrigation system, buildings, a fuel tank, and pumps) using the capital recovery method. This method helps growers calculate an annual amount of money to charge the enterprise so that the value of assets is recovered within a specified period of time at a designated rate of interest. The rate of interest used to calculate ownership cost is 7.40 percent-California's long-term average return rate on agricultural production assets from current income. Because farms use a mix of old and new equipment, we evaluated the value of the equipment complement at 60 percent of new prices.

\section{EQUIPMENT OPERATING CASH COSTS}

Equipment operating cash costs for fuel, lubrication, and repairs are calculated using formulas and coefficients developed by the American Society of Agricultural Engineers (ASAE). Repair costs are based on purchase price, annual hours of use, total hours of life, and repair coefficients formulated by the ASAE. Fuel and lubrication costs are also determined by ASAE equations based on machinery horsepower (maximum PTO hp) and type of fuel used. Fuel costs are calculated using average (1996 to 1999 period), on-farm delivery prices of $\$ 0.72$ per gallon for diesel and $\$ 1.20$ per gallon for gasoline. The cost of energy for electric irrigation pumps is $\$ 0.105$ per $\mathrm{kW}$.

\section{LA B O R}

Labor includes owner and hired operator labor with the same wage rate. Hourly labor wages are $\$ 7.50$ per hour for machine operators and $\$ 6.25$ per hour for other workers. These wages are averages based on data from the growers we interviewed. Growers also pay 20 to 34 percent for benefits, which include Workers Compensation, Social Security, Medicare insurance, and other possible benefits. In this study, we assumed an additional 34 percent for benefits, which brings the labor rate to about $\$ 10.00$ per hour for machine operators and $\$ 8.40$ per hour for other workers.

We calculated 20 percent additional labor time for machinery operation than the estimated time spent on the actual operation. This percentage accounts for the setup, moving, maintenance, and repair of equipment.

Table A. Harvested acreage, average yield, and average prices for cilantro, Ventura County, 1995-1999

\begin{tabular}{lcrc}
\hline Year & $\begin{array}{c}\text { Harvested } \\
\text { acreage }\end{array}$ & $\begin{array}{c}\text { Cartons } \\
\text { per acre* }\end{array}$ & $\begin{array}{c}\text { Price per } \\
\text { carton (\$) }\end{array}$ \\
\hline 1995 & 1,406 & 966 & 4.61 \\
1996 & 1,792 & 1,113 & 3.87 \\
1997 & 1,514 & 1,211 & 3.67 \\
1998 & 1,573 & 1,122 & 4.06 \\
1999 & 1,520 & 958 & 4.67 \\
Approximate \\
average 1,561 \\
*0ne carton equals 20 pounds.
\end{tabular}

\section{PRICES AND YIELDS}

Growers did not provide sufficient data on yield or prices, so we used average prices and yields provided by Ventura County Agricultural Crop Reports for the 1995 to 1999 period (table A) to estimate gross returns. The county crop reports use free on board (f.o.b.) prices to estimate growers' returns. These prices include harvesting and packing costs, but growers' prices may be different if they incur postharvest costs such as selling and cooling.

\section{SUMMARY OF COSTS}

Our sample estimate of the total cost of cilantro production in Ventura County is $\$ 4,385$ per acre (tables 1 and 2 ). Table 1 presents costs by type of activity, and table 2 presents costs by type of input. 
The pie graph below shows the breakdown of costs. It consists of about 16 percent for land preparation, planting, and growing costs, 68 percent for harvest and postharvest, 11 percent for cash overhead, 1 percent for interest on operating capital, and 4 percent for non-cash overhead costs. Land preparation, planting, and growing costs include fuel, lube, and machinery repairs, as well as materials and labor for all production practices. Harvesting costs in this study include the cost of the cartons, picking and packing, loading and hauling to the nearest cooling facility, and selling. Postharvest costs include two discings. Cash overhead costs include land rent, office expenses, liability insurance, supervisor and foremen wages, property taxes and insurance, and investment repairs.

Figure 1. Proportion of production costs for cilantro, Ventura County, 1999.

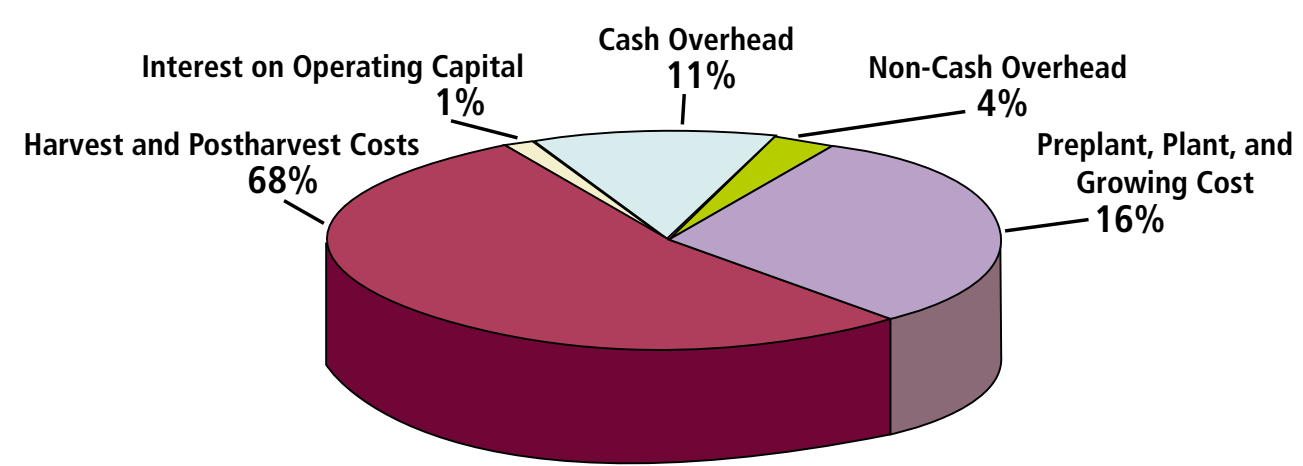

\section{PROFITABILITY ANALYSIS}

We analyzed profitability using break-even costs per carton and gross and economic margins. Break-even costs allow growers to compare expected market prices with the unit cost of production.

Gross margin (or returns above cash costs) is what growers often refer to as profit if there is no debt on the farming operation. It approximates the return to management and investment. If you deduct depreciation, it also approximates taxable income.

Economic profit (or returns above total cost including management) is a very useful measure of how attractive the enterprise is for potential investors and entrants into the business. Economic profit can be positive or zero. A zero economic profit should not be alarming if all costs, including the owners' labor and management costs, are included (and assumed paid) in the production cost. In this study, we do not include management charges, so the return after all costs are deducted reflects return to management.

Given the assumptions upon which we based this cost study, the break-even price for the 5-year county average yield of 1,070 cartons per acre is estimated at about $\$ 3.94$ per carton to cover all cash costs and $\$ 4.10$ per carton to cover total costs (table 4 , part A). At the same time, the break-even yield for the county average price of $\$ 4.20$ per carton is about 1,003 cartons per acre for cash costs and 1,044 cartons per acre for total costs. Break-even price is calculated as the cost of production per acre divided by the yield per acre. Break-even yield is calculated as cost of production divided by price per carton.

Gross margin for the county average yield and price is estimated at $\$ 281$ per acre (table 4, part C). This is calculated as gross returns (price multiplied by yield) minus cash costs of production. Returns to management for the county average yield and price are estimated at $\$ 109$ per acre (table 4 , part D). This figure is calculated as gross returns minus total (cash and non-cash) costs of production. 
Crop yield and prices received by growers, however, vary depending on several factors. Selling and cooling costs, in particular, influence prices, depending on whether the costs are incurred by the grower or by the buyer.

We have provided a range analyses of price and yield variations on profitability so that growers can determine their specific situation. The range analyses include break-even prices at various yield and gross margins and returns to management at various yield and price combinations. The gross margin and returns to management ranges are analyzed at increments of $\$ 0.10$ per carton for prices and 50 cartons per acre for yield (table 4, parts A through D). 
Table 1. Costs per acre to produce cilantro, Ventura County, 1999 (labor rates: $\$ 10.00 / \mathrm{hr}$ for machine labor, $\$ 8.40 / \mathrm{hr}$ for nonmachine labor; interest rate: $10.00 \%$ )

\begin{tabular}{|c|c|c|c|c|c|c|c|}
\hline \multirow[b]{2}{*}{ Operation } & \multirow{2}{*}{$\begin{array}{l}\text { Operation } \\
\text { time } \\
\text { (hrs/ac) } \\
\end{array}$} & \multicolumn{5}{|c|}{ Costs per acre (\$) } & \multirow[b]{2}{*}{$\begin{array}{c}\text { Your } \\
\text { cost (\$) }\end{array}$} \\
\hline & & $\begin{array}{c}\text { Labor } \\
\text { cost }\end{array}$ & $\begin{array}{l}\text { Fuel, lube, } \\
\& \text { repairs }\end{array}$ & $\begin{array}{c}\text { Material } \\
\text { cost }\end{array}$ & $\begin{array}{l}\text { Custom/ } \\
\text { rent }\end{array}$ & $\begin{array}{l}\text { Total } \\
\text { cost }\end{array}$ & \\
\hline \multicolumn{8}{|l|}{ Preplant: } \\
\hline Disc $2 x$ & 0.38 & 5 & 5 & 0 & 0 & 9 & \\
\hline $\operatorname{Rip} 2 x$ & 0.57 & 7 & 1 & 0 & 0 & 8 & \\
\hline Plow & 0.21 & 3 & 3 & 0 & 0 & 6 & \\
\hline Disc $3 \mathrm{x}$ & 0.57 & 7 & 8 & 0 & 0 & 15 & \\
\hline Landplane $3 x$ & 0.55 & 7 & 6 & 0 & 0 & 13 & \\
\hline Chisel & 0.25 & 3 & 4 & 0 & 0 & 7 & \\
\hline List and preplant fertilize & 0.33 & 7 & 4 & 66 & 0 & 77 & \\
\hline Shape beds \& roll & 0.23 & 3 & 2 & 0 & 0 & 5 & \\
\hline Sprinkler setup (machine \& labor) & 0.20 & 15 & 1 & 0 & 0 & 16 & \\
\hline Preplant irrigate (sprinkler) & 0.90 & 8 & 0 & 5 & 0 & 13 & \\
\hline \multicolumn{8}{|l|}{ Fuel/electricity for } \\
\hline irrigation pumps (preplant) & 0 & 0 & 0 & 4 & 0 & 4 & \\
\hline TOTAL PREPLANT COSTS & 4.19 & 62 & 34 & 75 & 0 & 171 & \\
\hline \multicolumn{8}{|l|}{ Plant: } \\
\hline Seeds (plant \& labor) & 0.22 & 3 & 4 & 175 & 0 & 181 & \\
\hline TOTAL PLANT COSTS & 0.22 & 3 & 4 & 175 & 0 & 181 & \\
\hline \multicolumn{8}{|l|}{ Growing: } \\
\hline Irrigate 5x (sprinkler) & 2.25 & 19 & 0 & 36 & 0 & 55 & \\
\hline \multicolumn{8}{|l|}{ Fuel/electricity for } \\
\hline irrigation pumps (growing) & 0 & 0 & 0 & 27 & 0 & 27 & \\
\hline \multicolumn{8}{|l|}{ Sprinkler removal (machine } \\
\hline \& labor) & 0.20 & 15 & 1 & 0 & 0 & 16 & \\
\hline Furrow setup (labor) & 0.40 & 3 & 0 & 0 & 0 & 3 & \\
\hline Irrigate 3x (furrow) & 0.90 & 8 & 0 & 41 & 0 & 49 & \\
\hline \multicolumn{8}{|l|}{ Electricity for } \\
\hline irrigation pump (growing) & 0 & 0 & 0 & 14 & 0 & 14 & \\
\hline Fertilize & 0 & 0 & 0 & 42 & 0 & 42 & \\
\hline Cultivate $2 x$ & 0.46 & 6 & 5 & 0 & 0 & 10 & \\
\hline Weed management $1 \mathrm{x}$ & 10.00 & 84 & 0 & 0 & 0 & 84 & \\
\hline Disease management $2 \mathrm{x}$ & 0.41 & 5 & 4 & 17 & 0 & 26 & \\
\hline Pest management $2 x$ & 0.41 & 5 & 4 & 9 & 0 & 18 & \\
\hline Pickup truck & 1.60 & 19 & 8 & 0 & 0 & 27 & \\
\hline TOTAL GROWING COSTS & 16.64 & 163 & 20 & 186 & 0 & 370 & \\
\hline \multicolumn{8}{|l|}{ Harvest \& Sell: } \\
\hline Harvest \& sell & 0 & 0 & 0 & 2,943 & 0 & 2,943 & \\
\hline \multicolumn{8}{|l|}{ TOTAL HARVEST } \\
\hline \& SELL COSTS & 0 & 0 & 0 & 2,943 & 0 & 2,943 & \\
\hline
\end{tabular}


Table 1. Continued

\begin{tabular}{|c|c|c|c|c|c|c|c|}
\hline \multirow[b]{2}{*}{ Operation } & \multirow{2}{*}{$\begin{array}{l}\text { Operation } \\
\text { time } \\
\text { (hrs/ac) } \\
\end{array}$} & \multicolumn{5}{|c|}{ Costs per acre (\$) } & \multirow[b]{2}{*}{$\begin{array}{c}\text { Your } \\
\text { cost (\$) }\end{array}$} \\
\hline & & $\begin{array}{c}\text { Labor } \\
\text { cost }\end{array}$ & $\begin{array}{l}\text { Fuel, lube, } \\
\text { \& repairs }\end{array}$ & $\begin{array}{c}\text { Material } \\
\text { cost }\end{array}$ & $\begin{array}{c}\text { Custom/ } \\
\text { rent }\end{array}$ & $\begin{array}{l}\text { Total } \\
\text { cost }\end{array}$ & \\
\hline \multicolumn{8}{|l|}{ Disposing of Crop Residue: } \\
\hline Postharvest disc $2 \mathrm{x}$ & 0.38 & 5 & 5 & 0 & 0 & 9 & \\
\hline \multicolumn{8}{|l|}{ TOTAL DISPOSING OF } \\
\hline CROP RESIDUE COSTS & 0.38 & 5 & 5 & 0 & 0 & 9 & \\
\hline \multicolumn{8}{|l|}{ Interest on operating capital } \\
\hline @ 10.00\% & & & & & & 36 & \\
\hline TOTAL OPERATING COS & CRE & 233 & 62 & 3,379 & 0 & 3,711 & \\
\hline
\end{tabular}

Cash Overhead:

Land rent

Office expense

Liability insurance

Supervisors \& foreman

Property taxes

Property insurance

Investment repairs

TOTAL CASH OVERHEAD COSTS

TOTAL CASH COSTSIACRE

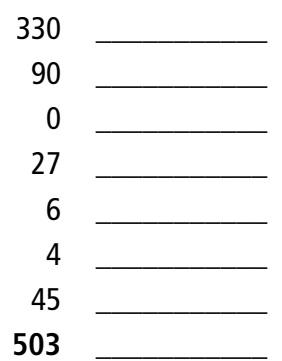

4,213

\begin{tabular}{|c|c|c|c|c|}
\hline & $\begin{array}{c}\text { Costs per } \\
\text { producing } \\
\text { acre (\$) }\end{array}$ & $\begin{array}{c}\text { Annual } \\
\text { cost: } \\
\text { capital } \\
\text { recovery }(\$)\end{array}$ & $\begin{array}{r}\text { Total } \\
\text { cost }(\$) \\
\end{array}$ & $\begin{array}{c}\text { Your } \\
\text { cost (\$) }\end{array}$ \\
\hline \multicolumn{5}{|l|}{ Non-cash Overhead: } \\
\hline \multicolumn{5}{|l|}{ Investment } \\
\hline Shop building & 23 & 3 & 3 & \\
\hline Shop tools & 12 & 1 & 1 & \\
\hline Fuel tanks \& pumps & 15 & 2 & 2 & \\
\hline Sprinklers and pipes & 549 & 76 & 76 & \\
\hline Irrigation pump & 333 & 46 & 46 & \\
\hline Equipment & 175 & 44 & 44 & \\
\hline TOTAL NON-CASH OVERHEAD COSTS & 1,106 & 171 & 171 & \\
\hline TOTAL COSTS/ACRE & & & 4,385 & \\
\hline
\end{tabular}


Table 2. Costs and returns per acre to produce cilantro, Ventura County, 1999 (labor rates: $\$ 10.00 / \mathrm{hr}$ for machine labor, $\$ 8.40 / \mathrm{hr}$ for non-machine labor; interest rate: $10.00 \%$ )

\begin{tabular}{|c|c|c|c|c|c|}
\hline & $\begin{array}{l}\text { Quantity } \\
\text { per acre }\end{array}$ & Unit & $\begin{array}{l}\text { Price or } \\
\text { cost per } \\
\text { unit }(\$)\end{array}$ & $\begin{array}{l}\text { Value or } \\
\text { cost per } \\
\text { acre }(\$)\end{array}$ & $\begin{array}{c}\text { Your } \\
\text { cost }(\$)\end{array}$ \\
\hline Gross Returns & 1,070 & carton & 4.20 & 4,494 & \\
\hline \multicolumn{6}{|l|}{ TOTAL GROSS RETURNS } \\
\hline FOR CILANTRO & & & & 4,494 & \\
\hline \multicolumn{6}{|l|}{ Operating Costs: } \\
\hline \multicolumn{6}{|l|}{ Fertilize: } \\
\hline 16-20-0 (preplant) & 400.00 & pound & 0.165 & 66 & \\
\hline AN 20 (growing) & 40.00 & gallon & 1.05 & 42 & \\
\hline \multicolumn{6}{|l|}{ Water: } \\
\hline Water & 12.00 & acre-inch & 6.83 & 82 & \\
\hline \multicolumn{6}{|l|}{ Fuel (pump): } \\
\hline Booster pump fuel & 24.00 & gallon & 0.72 & 17 & \\
\hline \multicolumn{6}{|l|}{ Electricity (pump): } \\
\hline Low-pressure pump & 268.80 & kW & 0.105 & 28 & \\
\hline \multicolumn{6}{|l|}{ Plant: } \\
\hline Seeds & 25.00 & pound & 7.00 & 175 & \\
\hline Disease management & 1.00 & acre & 17.00 & 17 & \\
\hline Pest management & 1.00 & acre & 9.00 & 9 & \\
\hline \multicolumn{6}{|l|}{ Harvest \& sell: } \\
\hline Cartons & $1,070.00$ & carton & 0.80 & 856 & \\
\hline Pick \& pack & $1,070.00$ & carton & 0.80 & 856 & \\
\hline Load \& haul & $1,070.00$ & carton & 0.65 & 696 & \\
\hline Sell & $1,070.00$ & carton & 0.50 & 535 & \\
\hline Labor (machine) & 8.38 & hour & 10.00 & 84 & \\
\hline Labor (non-machine) & 17.77 & hour & 8.40 & 149 & \\
\hline \multicolumn{6}{|l|}{ Fuel: } \\
\hline Gasoline & 4.0 & gallon & 1.20 & 5 & \\
\hline Diesel & 36.90 & gallon & 0.72 & 27 & \\
\hline Lube & & & & 5 & \\
\hline Machinery repair & & & & 26 & \\
\hline \multicolumn{6}{|l|}{ Interest on operating } \\
\hline capital @ 10.00\% & & & & 36 & \\
\hline \multicolumn{2}{|c|}{ TOTAL OPERATING COSTS/ACRE } & & & 3,711 & \\
\hline \multicolumn{3}{|c|}{ NET RETURNS ABOVE OPERATING COSTS } & & 783 & \\
\hline \multicolumn{6}{|l|}{ Cash Overhead Costs: } \\
\hline \multicolumn{2}{|l|}{ Land rent } & & & 330 & \\
\hline \multicolumn{2}{|l|}{ Office expense } & & & 90 & \\
\hline \multicolumn{2}{|l|}{ Liability insurance } & & & 0 & \\
\hline \multicolumn{2}{|l|}{ Supervisors \& foreman } & & & 27 & \\
\hline \multicolumn{2}{|l|}{ Property taxes } & & & 6 & \\
\hline \multicolumn{2}{|l|}{ Property insurance } & & & 4 & \\
\hline \multicolumn{2}{|c|}{ Investment repairs } & & & 45 & \\
\hline \multicolumn{2}{|c|}{ TOTAL CASH OVERHEAD COSTSIACRE } & & & 503 & \\
\hline TOTAL CASH COSTSIAC & & & & 4,213 & \\
\hline
\end{tabular}


Table 2. Continued

\begin{tabular}{|c|c|c|c|c|}
\hline $\begin{array}{l}\text { Quantity } \\
\text { per acre }\end{array}$ & Unit & $\begin{array}{l}\text { Price or } \\
\text { cost per } \\
\text { unit }(\$)\end{array}$ & $\begin{array}{l}\text { Value or } \\
\text { cost per } \\
\text { acre (\$) }\end{array}$ & $\begin{array}{c}\text { Your } \\
\text { cost (\$) }\end{array}$ \\
\hline \multicolumn{5}{|l|}{ Non-cash Overhead Costs (Capital Recovery): } \\
\hline Shop building & & & 3 & \\
\hline Shop tools & & & 1 & \\
\hline Fuel tanks \& pumps & & & 2 & \\
\hline Sprinklers \& pipes & & & 76 & \\
\hline Irrigation pump & & & 46 & \\
\hline Equipment & & & 44 & \\
\hline TOTAL NON-CASH OVERHEAD COSTS/ACRE & & & 171 & \\
\hline TOTAL COSTS/ACRE & & & 4,385 & \\
\hline NET RETURNS ABOVE TOTAL COSTS & & & 109 & \\
\hline
\end{tabular}


Table 3. Monthly cash costs per acre to produce cilantro, Ventura County, 1999

\begin{tabular}{|c|c|c|c|c|}
\hline \multirow[b]{2}{*}{ Operation } & \multicolumn{4}{|c|}{ Costs per acre $(\$)$} \\
\hline & Month 1 & Month 2 & Month 3 & Total \\
\hline \multicolumn{5}{|l|}{ Preplant: } \\
\hline Disc $2 x$ & 9 & & & 9 \\
\hline Rip 2x & 8 & & & 8 \\
\hline Plow & 6 & & & 6 \\
\hline Disc $3 x$ & 15 & & & 15 \\
\hline Landplane $3 x$ & 13 & & & 13 \\
\hline Chisel & 7 & & & 7 \\
\hline List and preplant fertilize & 77 & & & 77 \\
\hline Shape beds \& roll & 5 & & & 5 \\
\hline Sprinkler setup (machine \& labor) & 16 & & & 16 \\
\hline Preplant irrigate (sprinkler) & 13 & & & 13 \\
\hline \multicolumn{5}{|l|}{ Fuel/electricity for } \\
\hline irrigation pumps (preplant) & 4 & & & 4 \\
\hline TOTAL PREPLANT COSTS & 171 & & & 171 \\
\hline \multicolumn{5}{|l|}{ Plant: } \\
\hline Seeds (plant \& labor) & & 181 & & 181 \\
\hline TOTAL PLANT COSTS & & 181 & & 181 \\
\hline \multicolumn{5}{|l|}{ Growing: } \\
\hline Irrigate 5x (sprinkler) & & 55 & & 55 \\
\hline \multicolumn{5}{|l|}{ Fuel/electricity for } \\
\hline irrigation pumps (growing) & & 27 & & 27 \\
\hline Sprinkler removal (machine \& labor) & & 16 & & 16 \\
\hline Furrow setup (labor) & & 3 & & 3 \\
\hline Irrigate 3x (furrow) & & 9 & 39 & 49 \\
\hline \multicolumn{5}{|l|}{ Electricity for irrigation } \\
\hline pump (growing) & & 2 & 12 & 14 \\
\hline Fertilize & & & 42 & 42 \\
\hline Cultivate $2 \mathrm{x}$ & & 5 & 5 & 10 \\
\hline Weed management $1 \mathrm{x}$ & & & 84 & 84 \\
\hline Disease management $2 \mathrm{x}$ & & 13 & 13 & 26 \\
\hline Pest management $2 \mathrm{x}$ & & 9 & 9 & 18 \\
\hline Pickup truck & 9 & 9 & 9 & 27 \\
\hline TOTAL GROWING COSTS & 9 & 149 & 213 & 370 \\
\hline \multicolumn{5}{|l|}{ Harvest \& Sell: } \\
\hline Harvest \& sell & & & 2,943 & 2,943 \\
\hline \multicolumn{5}{|l|}{ TOTAL HARVEST } \\
\hline \& SELL COSTS & & & 2,943 & 2,943 \\
\hline \multicolumn{5}{|l|}{ Disposing of Crop Residue: } \\
\hline Postharvest disc $2 \mathrm{x}$ & & & 9 & 9 \\
\hline \multicolumn{5}{|l|}{ TOTAL DISPOSING OF } \\
\hline CROP RESIDUE COSTS & & & 9 & 9 \\
\hline \multicolumn{5}{|l|}{ Interest on operating capital } \\
\hline @ $10.00 \%$ & 2 & 4 & 31 & 36 \\
\hline TOTAL OPERATING COSTS/ACRE & 182 & 334 & 3,195 & 3,711 \\
\hline
\end{tabular}


Table 3. Continued

\begin{tabular}{lrrrr}
\hline & \multicolumn{4}{c}{ Costs per acre (\$) } \\
\cline { 2 - 4 } Operation & Month 1 & Month 2 & Month 3 & Total \\
\hline Cash Overhead: & 110 & 110 & 110 & 330 \\
Land rent & 30 & 30 & 30 & 90 \\
Office expense & 0 & 0 & 0 & 0 \\
Liability insurance & 9 & 9 & 9 & 27 \\
Supervisors \& foreman & 3 & & 3 & 6 \\
Property taxes & 2 & & 2 & 4 \\
Property insurance & 15 & 15 & 15 & 45 \\
Investment repairs & 169 & 165 & 503 \\
$\quad$ TOTAL CASH OVERHEAD COSTS & 351 & 499 & 3,364 & 4,213 \\
TOTAL CASH COSTS/ACRE & & & & \\
\hline
\end{tabular}


Table 4. Range analyses of cilantro production costs and returns, Ventura County, 1999

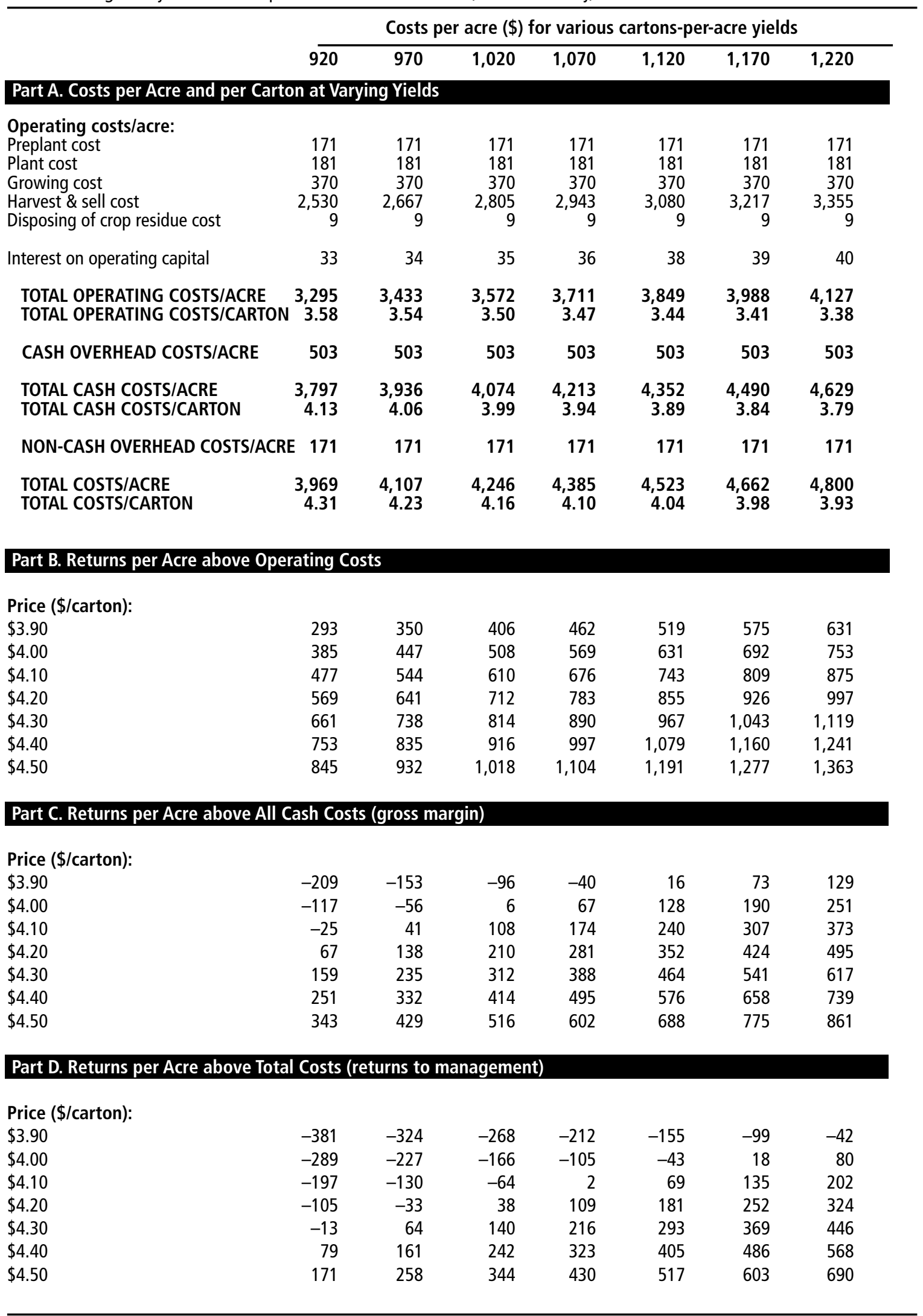


Table 5. Farm equipment and investment values and annual costs based on 2,600 annual farmed acres, Ventura County, 1999

\begin{tabular}{|c|c|c|c|c|c|c|c|}
\hline \multirow[b]{3}{*}{ Equipment } & \multirow{3}{*}{$\begin{array}{c}\text { Value: } \\
1999 \\
\text { price (\$) }\end{array}$} & \multirow[b]{3}{*}{ Life (yrs) } & \multirow{3}{*}{$\begin{array}{c}\text { Salvage } \\
\text { value } \\
(\$)\end{array}$} & \multicolumn{4}{|c|}{ Costs } \\
\hline & & & & \multirow{2}{*}{$\begin{array}{c}\text { Capital } \\
\text { recovery } \\
(\$)\end{array}$} & \multicolumn{2}{|c|}{$\begin{array}{l}\text { Annual cash } \\
\text { overhead (\$) }\end{array}$} & \multirow{2}{*}{$\begin{array}{c}\text { Total } \\
\text { annual } \\
\text { costs (\$) }\end{array}$} \\
\hline & & & & & Insurance & Taxes & \\
\hline 120 HP Tractor 4WD (\#1) & 75,180 & 6 & 7,518 & 14,927 & 295 & 413 & 15,636 \\
\hline 120 HP Tractor 4WD (\#2) & 75,180 & 5 & 7,518 & 17,236 & 295 & 413 & 17,944 \\
\hline 120 HP Tractor 4WD (\#3) & 75,180 & 6 & 7,518 & 14,927 & 295 & 413 & 15,636 \\
\hline 200 HP 4WD Tractor & 135,500 & 6 & 13,550 & 26,904 & 531 & 745 & 28,181 \\
\hline 45 HP 2WD Tractor & 23,030 & 10 & 2,303 & 3,176 & 90 & 127 & 3,393 \\
\hline Bed shaper & 8,900 & 3 & 890 & 3,140 & 35 & 49 & 3,224 \\
\hline Chisel - 14' (\#1) & 2,270 & 3 & 227 & 801 & 9 & 12 & 822 \\
\hline Chisel - 14' (\#2) & 2,270 & 3 & 227 & 801 & 9 & 12 & 822 \\
\hline Cultivator - 4-row 40" (\#1) & 7,130 & 3 & 713 & 2,516 & 28 & 39 & 2,583 \\
\hline Cultivator - 4-row 40" (\#2) & 7,130 & 3 & 713 & 2,516 & 28 & 39 & 2,583 \\
\hline Disc - 21' (\#1) & 16,510 & 5 & 1,651 & 3,785 & 65 & 91 & 3,941 \\
\hline Disc - 21' (\#2) & 16,510 & 5 & 1,651 & 3,785 & 65 & 91 & 3,941 \\
\hline Disc - 21' (\#3) & 16,510 & 5 & 1,651 & 3,785 & 65 & 91 & 3,941 \\
\hline Disc - 21' (\#4) & 16,510 & 5 & 1,651 & 3,785 & 65 & 91 & 3,941 \\
\hline Disc - 21' (\#5) & 16,510 & 5 & 1,651 & 3,785 & 65 & 91 & 3,941 \\
\hline Disc - 21' (\#6) & 16,510 & 5 & 1,651 & 3,785 & 65 & 91 & 3,941 \\
\hline Disc - 21' (\#7) & 16,510 & 5 & 1,651 & 3,785 & 65 & 91 & 3,941 \\
\hline Lister (\#1) & 6,000 & 4 & 600 & 1,653 & 24 & 33 & 1,710 \\
\hline Lister (\#2) & 6,000 & 4 & 600 & 1,653 & 24 & 33 & 1,710 \\
\hline Pickup truck $1 / 2$ ton $(\# 1)$ & 17,160 & 2 & 1,716 & 8,716 & 67 & 94 & 8,878 \\
\hline Pickup truck $1 / 2$ ton (\#2) & 17,160 & 2 & 1,716 & 8,716 & 67 & 94 & 8,878 \\
\hline Pickup truck $1 / 2$ ton $(\# 3)$ & 17,160 & 2 & 1,716 & 8,716 & 67 & 94 & 8,878 \\
\hline Pickup truck 1/2 ton (\#4) & 17,160 & 2 & 1,716 & 8,716 & 67 & 94 & 8,878 \\
\hline Pickup truck 1/2 ton (\#5) & 17,160 & 2 & 1,716 & 8,716 & 67 & 94 & 8,878 \\
\hline Planter - 6-row & 8,900 & 5 & 890 & 2,040 & 35 & 49 & 2,124 \\
\hline Plow - 6-bottom & 12,000 & 3 & 180 & 4,550 & 43 & 61 & 4,655 \\
\hline Sprayer 600 gallon (\#1) & 100,000 & 5 & 10,000 & 22,926 & 392 & 550 & 23,868 \\
\hline Sprayer 600 gallon (\#2) & 100,000 & 5 & 10,000 & 22,926 & 392 & 550 & 23,868 \\
\hline Subsoiler - 12' (\#1) & 6,490 & 2 & 649 & 3,297 & 25 & 36 & 3,358 \\
\hline Subsoiler - 12' (\#2) & 6,490 & 2 & 649 & 3,297 & 25 & 36 & 3,358 \\
\hline Trailer & 2,000 & 2 & 200 & 1,016 & 8 & 11 & 1,035 \\
\hline Triplane - 14' (\#1) & 18,230 & 5 & 1,823 & 4,179 & 71 & 100 & 4,351 \\
\hline Triplane - 14' (\#2) & 18,230 & 5 & 1,823 & 4,179 & 71 & 100 & 4,351 \\
\hline Triplane - 14' (\#3) & 18,230 & 5 & 1,823 & 4,179 & 71 & 100 & 4,351 \\
\hline TOTAL EQUIPMENT & 915,710 & & 90,551 & 232,916 & 3,587 & 5,031 & 241,535 \\
\hline $60 \%$ OF NEW COST* & 549,426 & & 54,331 & 139,750 & 2,152 & 3,019 & 144,921 \\
\hline
\end{tabular}

*Used to reflect a mix of new and used equipment. 
Table 5. Continued

\begin{tabular}{|c|c|c|c|c|c|c|c|c|}
\hline \multirow[b]{3}{*}{ Investment } & \multirow{3}{*}{$\begin{array}{c}\text { Value: } \\
1999 \\
\text { price (\$) }\end{array}$} & \multirow[b]{3}{*}{ Life (yrs) } & \multirow{3}{*}{$\begin{array}{c}\text { Salvage } \\
\text { value } \\
\text { (\$) }\end{array}$} & \multicolumn{5}{|c|}{ Costs } \\
\hline & & & & \multirow{2}{*}{$\begin{array}{l}\text { Capital } \\
\text { recovery } \\
(\$)\end{array}$} & \multicolumn{3}{|c|}{$\begin{array}{l}\text { Annual cash } \\
\text { overhead (\$) }\end{array}$} & \multirow{2}{*}{$\begin{array}{c}\text { Total } \\
\text { annual } \\
\text { costs }(\$)\end{array}$} \\
\hline & & & & & Insurance & Taxes & Repairs & \\
\hline Fuel tanks \& pumps & 38,100 & 15 & 3,810 & 4,142 & 149 & 210 & 1,828 & 6,329 \\
\hline Irrigation pump & 866,666 & 10 & 86,667 & 119,529 & 3,399 & 4,767 & 41,599 & 169,293 \\
\hline Shop building & 60,000 & 15 & 6,000 & 6,524 & 235 & 330 & 2,880 & 9,969 \\
\hline Shop tools & 30,000 & 15 & 3,000 & 3,262 & 118 & 165 & 1,440 & 4,984 \\
\hline Sprinklers \& pipes & $1,427,530$ & 10 & 142,753 & 196,883 & 5,598 & 7,851 & 68,521 & 278,853 \\
\hline \multirow[t]{2}{*}{ TOTAL INVESTMENT } & $2,422,296$ & & 242,230 & 330,340 & 9,499 & 13,323 & 116,268 & 469,429 \\
\hline & & & $\begin{array}{l}\text { Enterprise/ } \\
\text { farm size }\end{array}$ & \multicolumn{2}{|c|}{ Unit } & $\begin{array}{r}\text { Price pe } \\
\text { unit (\$) }\end{array}$ & \multicolumn{2}{|c|}{$\begin{array}{c}\text { Total } \\
\text { cost }(\$)\end{array}$} \\
\hline \multicolumn{2}{|l|}{ Land rent } & & 2,600 & \multicolumn{2}{|c|}{ acre } & 330 & \multicolumn{2}{|c|}{858,000} \\
\hline Liability insurance & & & 2,600 & \multicolumn{2}{|c|}{ acre } & 0.40 & \multicolumn{2}{|c|}{1,040} \\
\hline Office expense & & & 2,600 & \multicolumn{2}{|c|}{ acre } & 90 & \multicolumn{2}{|c|}{234,000} \\
\hline Supervisors \& foreman & & & 2,600 & \multicolumn{2}{|c|}{ acre } & 27 & \multicolumn{2}{|c|}{70,200} \\
\hline
\end{tabular}


Table 6. Farm equipment actual hours of use and hourly costs based on 2,600 annual farmed acres, Ventura County, 1999

\begin{tabular}{|c|c|c|c|c|c|c|c|}
\hline \multirow[b]{4}{*}{ Description } & \multirow{4}{*}{$\begin{array}{l}\text { Actual } \\
\text { hours } \\
\text { of use }\end{array}$} & \multicolumn{6}{|c|}{ Costs per hour (\$) } \\
\hline & & \multirow{3}{*}{$\begin{array}{l}\text { Capital } \\
\text { recovery }\end{array}$} & \multirow{2}{*}{\multicolumn{2}{|c|}{ Cash overhead }} & \multicolumn{2}{|c|}{ Operating } & \multirow{3}{*}{$\begin{array}{c}\text { Total } \\
\text { costs } \\
\text { per hour }\end{array}$} \\
\hline & & & & & & Fuel & \\
\hline & & & Insurance & Taxes & Repairs & \& lube & \\
\hline 120 HP Tractor 4WD (\#1) & 2,500 & 3.58 & 0.07 & 0.10 & 1.89 & 5.77 & 11.41 \\
\hline 120 HP Tractor 4WD (\#2) & 3,000 & 3.45 & 0.06 & 0.08 & 1.91 & 5.77 & 11.27 \\
\hline 120 HP Tractor 4WD (\#3) & 2,500 & 3.58 & 0.07 & 0.10 & 1.89 & 5.77 & 11.41 \\
\hline 200 HP 4WD Tractor & 2,600 & 6.21 & 0.12 & 0.17 & 3.54 & 9.61 & 19.65 \\
\hline 45 HP 2WD Tractor & 1,200 & 1.59 & 0.05 & 0.06 & 1.03 & 1.83 & 4.55 \\
\hline Bed shaper & 670 & 2.81 & 0.03 & 0.04 & 1.53 & 0 & 4.42 \\
\hline Chisel - 14' (\#1) & 740 & 0.65 & 0.01 & 0.01 & 0.44 & 0 & 1.11 \\
\hline Chisel - 14' (\#2) & 740 & 0.65 & 0.01 & 0.01 & 0.44 & 0 & 1.11 \\
\hline Cultivator - 4-row 40" (\#1) & 740 & 2.04 & 0.02 & 0.03 & 1.39 & 0 & 3.49 \\
\hline Cultivator - 4-row 40" (\#2) & 740 & 2.04 & 0.02 & 0.03 & 1.39 & 0 & 3.49 \\
\hline Disc - 21' (\#1) & 500 & 4.54 & 0.08 & 0.11 & 3.65 & 0 & 8.38 \\
\hline Disc - 21' (\#2) & 500 & 4.54 & 0.08 & 0.11 & 3.65 & 0 & 8.38 \\
\hline Disc - 21' (\#3) & 500 & 4.54 & 0.08 & 0.11 & 3.65 & 0 & 8.38 \\
\hline Disc - 21' (\#4) & 500 & 4.54 & 0.08 & 0.11 & 3.65 & 0 & 8.38 \\
\hline Disc - 21' (\#5) & 500 & 4.54 & 0.08 & 0.11 & 3.65 & 0 & 8.38 \\
\hline Disc - 21' (\#6) & 500 & 4.54 & 0.08 & 0.11 & 3.65 & 0 & 8.38 \\
\hline Disc - 21' (\#7) & 500 & 4.54 & 0.08 & 0.11 & 3.65 & 0 & 8.38 \\
\hline Lister (\#1) & 500 & 1.98 & 0.03 & 0.04 & 2.60 & 0 & 4.65 \\
\hline Lister (\#2) & 500 & 1.98 & 0.03 & 0.04 & 2.60 & 0 & 4.65 \\
\hline Pickup truck 1/2 ton (\#1) & 1,000 & 5.23 & 0.04 & 0.06 & 1.29 & 3.45 & 10.06 \\
\hline Pickup truck 1/2 ton (\#2) & 1,000 & 5.23 & 0.04 & 0.06 & 1.29 & 3.45 & 10.06 \\
\hline Pickup truck 1/2 ton (\#3) & 1,000 & 5.23 & 0.04 & 0.06 & 1.29 & 3.45 & 10.06 \\
\hline Pickup truck 1/2 ton (\#4) & 1,000 & 5.23 & 0.04 & 0.06 & 1.29 & 3.45 & 10.06 \\
\hline Pickup truck 1/2 ton (\#5) & 1,000 & 5.23 & 0.04 & 0.06 & 1.29 & 3.45 & 10.06 \\
\hline Planter - 6-row & 500 & 2.45 & 0.04 & 0.06 & 1.97 & 0 & 4.52 \\
\hline Plow - 6-bottom & 610 & 4.48 & 0.04 & 0.06 & 1.82 & 0 & 6.40 \\
\hline Sprayer 600 gallon (\#1) & 2,000 & 6.88 & 0.12 & 0.17 & 4.80 & 3.31 & 15.27 \\
\hline Sprayer 600 gallon (\#2) & 2,000 & 6.88 & 0.12 & 0.17 & 4.80 & 3.31 & 15.27 \\
\hline Subsoiler - 12' (\#1) & 840 & 2.35 & 0.02 & 0.03 & 1.28 & 0 & 3.68 \\
\hline Subsoiler - 12' (\#2) & 840 & 2.35 & 0.02 & 0.03 & 1.28 & 0 & 3.68 \\
\hline Trailer & 1,000 & 0.61 & 0.01 & 0.01 & 0.35 & 0 & 0.97 \\
\hline Triplane - 14' (\#1) & 540 & 4.64 & 0.08 & 0.11 & 2.74 & 0 & 7.57 \\
\hline Triplane - 14' (\#2) & 540 & 4.64 & 0.08 & 0.11 & 2.74 & 0 & 7.57 \\
\hline Triplane - 14' (\#3) & 540 & 4.64 & 0.08 & 0.11 & 2.74 & 0 & 7.57 \\
\hline
\end{tabular}




\section{REFERENCES}

American Society of Agricultural Engineers. 1992. American Society of Agricultural Engineers Standards Yearbook. St. Joseph, MI: ASAE.

Boelje, M. D., and V. R. Eidman. 1984. Farm management. New York: John Wiley and Sons.

Brendler, R. A. 1990. Costs and practices in Ventura County for lima beans and vegetables. Ventura: University of California Cooperative Extension, Ventura County.

Laemmlen, F. F., and R. Smith. 1998. Cilantro production in California. Oakland: University of California Division of Agriculture and Natural Resources. Publication 7236.

Ventura County Agricultural Commissioner. 1998. Ventura County Annual Crop Report. Santa Paula, CA: County Agricultural Commissioner. 


\section{FOR MORE INFORMATION}

You'll find detailed information on many aspects of vegetable production in these titles and in other publications, slide sets, and videos from UC ANR:

Specialty and Minor Crops Handbook, publication 3346

Pesticides for Specialty Crops, publication 7253

Commercial Cooling of Fruits, Vegetables, and Flowers, publication 21567

To order these products, visit our online catalog at http://anrcatalog.ucdavis.edu. You can also place orders by mail, phone, or fax, or request a printed catalog of publications, slide sets, and videos from

\section{University of California}

Agriculture and Natural Resources

Communication Services

6701 San Pablo Avenue, 2nd Floor

Oakland, CA 94608-1239

Telephone: (800) 994-8849 or (510) 642-2431, FAX: (510) 643-5470

E-mail inquiries: danrcs@ucdavis.edu

An electronic version of this publication is available on the ANR Communication Services website at http://anrcatalog.ucdavis.edu.

\section{Publication 8029}

To simplify information, trade names of some products have been used in this report. No endorsement of named products is intended, nor is criticism implied of similar products that are not mentioned.

(C)2001 by the Regents of the University of California, Division of Agriculture and Natural Resources. All rights reserved.

The University of California prohibits discrimination against or harassment of any person employed by or seeking employment with the University on the basis of race, color, national origin, religion, sex, physical or mental disability, medical condition (cancer-related or genetic characteristics), ancestry, marital status, age, sexual orientation, citizenship, or status as a covered veteran (special disabled veteran, Vietnam-era veteran or any other veteran who served on active duty during a war or in a campaign or expedition for which a campaign badge has been authorized). University Policy is intended to be consistent with the provisions of applicable State and Federal laws.

Inquiries regarding the University's nondiscrimination policies may be directed to the Affirmative Action/Staff Personnel Services Director, University of California, Agriculture and Natural Resources, 300 Lakeside Drive, 6th floor, Oakland, CA 94612-3550; (510) 987-0096. For a free catalog of other publications, telephone (800) 994-8849.

pr-09/01-GM/VFG

ISBN 978-1-60107-207-8

This publication has been anonymously peer reviewed for technical accuracy by University of California scientists and other qualified professionals. This review process was managed by the ANR Associate Editor for Vegetable Crops. 